\title{
NOVÝ KMEN TUBERKULÓZY
}

\section{Jiří Patočka, Bohumír Plucar}

Jihočeská univerzita v Českých Budějovicích, Zdravotně sociální fakulta, katedra radiologie a toxikologie

Univerzita Karlova v Praze, 1. lékařská fakulta, Ústav pro humanitní studia v lékařství

Jižní Afrika je nejen zemí s vysokým procentem HIV-pozitivních osob, ale i zemí, kde se v poslední době objevil nový kmen bakterie Mycobacterium tuberculosis s rozsáhlou rezistencí na léky, označovaný jako XDR-TB (extensively drug-resistant tuberculosis) (MMWR Morbidity and Mortality Weekly Report 55, 301, 2006). Nemoc se vyznačuje téměr stoprocentní morbiditou. Z třiapadesáti pacientů $\mathrm{v}$ provincii Kwazulu-Natal, u nichž byla v záŕí 2006 prokázána tuberkulóza vyvolaná kmeny XDR-TB, přežil jen jediný. Od té doby se oficiální počty obětí XDR-TB zvýšily na 74.

Všichni jihoafričtí pacienti trpící XDR-TB, kteři mohli být podrobeni lékařským testům, byli HIV pozitivní. Osoby, nakažené virem HIV, mají ochromený imunitní systém a podléhají velkému množství nejrůznějších infekcí. Velká část lidí s AIDS umírá právě na tuberkulózu.

Př́pady tuberkulózy XDR-TB v Jihoafrické republice byly objeveny jen díky tomu, že vědci z Harvardské univerzity zahájili studii, jejímž cílem bylo zkoumat míru odolnosti nemocí vưči lékům. $\mathrm{V}$ jiných částech Afriky, kde žádní vědci nejsou a nejsou tam ani zdravotnická zařizení, která by byla schopna pacienty diagnostikovat či dokonce jen registrovat, počty nemocných nejsou známy. Počty nemocných jsou zřejmě značné a protože nemoc se snadno širrí v uzavřených prostorách, jako jsou letadla, je nebezpečí další nákazy obrovské (Lancet 368 (9540), 964, 2006).

Jihoafričtí lékaři se proto rozhodli vyhlásit této zákeřné nemoci nekompromisní boj. Požadují, aby nakažené osoby, které se dobrovolně nepodvolí karanténním opatřením, mohly $\mathrm{k}$ tomu být donuceny násilím. Boj s XDR-TB dosud naráží na velké problémy vyplývající s nejasností kolem lékařské etiky. Jihoafričtí odborníci na lékařskou etiku jsou však přesvědčeni, že takový postup je adekvátní obrovskému nebezpečí této choroby, které pramení z nekontrolovaného pohybu nakažených osob (Singh J. A., Upshur, R., Padayatchi, N., PLoS Medicine Vol. 4, No. 1, 50, 2007. doi: 10.1371/ journal. pmed. 0040050).

Jiří Patočka a Bohumír Plucar prof.patocka@gmail.com

\section{ETICKÁ PRAVIDLA PRO ROBOTY}

\section{Jiří Patočka}

Jihočeská univerzita v Českých Budějovicích, Zdravotně sociální fakulta, katedra radiologie a toxikologie

Rychlý pokrok na poli robotiky a stále rostoucí inteligence robotů privedla jihokorejské ministerstvo obchodu, průmyslu a energetiky $\mathrm{k}$ přesvědčení, že mají-li roboti žít s lidmi, je nutné vypracovat pro jejich chování etické normy. Jihokorejská vláda považuje robotiku za klíčový hnací motor ekonomiky země a investuje miliony dolarů do výzkumu. Jižní Korea je jedním z technicky nejvyspělejších států světa a jihokorejské ministerstvo informací a spojů předpovědělo, že do deseti let budou roboti běžně provádět chirurgické operace a do roku 2015 až 2020 